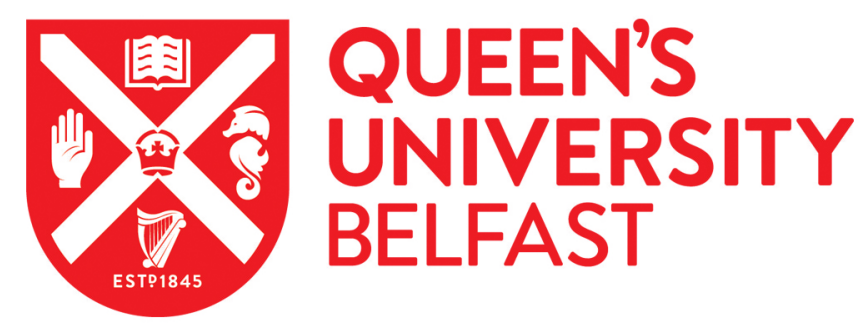

\title{
The processes underlying the quality of contact with the primary out- group and in-group importance on support for the Syrian resettlement in a post-accord context.
}

Schulz, M., \& Taylor, L. K. (2018). The processes underlying the quality of contact with the primary out-group and in-group importance on support for the Syrian resettlement in a post-accord context. Peace and Conflict: Journal of Peace Psychology , 24(3), 306-314. https://doi.org/10.1037/pac0000321

Published in:

Peace and Conflict: Journal of Peace Psychology

Document Version:

Peer reviewed version

Queen's University Belfast - Research Portal:

Link to publication record in Queen's University Belfast Research Portal

Publisher rights

Copyright 2017 American Psychological Association. This work is made available online in accordance with the publisher's policies. Please refer to any applicable terms of use of the publisher.

\section{General rights}

Copyright for the publications made accessible via the Queen's University Belfast Research Portal is retained by the author(s) and / or other copyright owners and it is a condition of accessing these publications that users recognise and abide by the legal requirements associated with these rights.

\section{Take down policy}

The Research Portal is Queen's institutional repository that provides access to Queen's research output. Every effort has been made to ensure that content in the Research Portal does not infringe any person's rights, or applicable UK laws. If you discover content in the Research Portal that you believe breaches copyright or violates any law, please contact openaccess@qub.ac.uk. 
The processes underlying the quality contact with the primary out-group and in-group importance on support for the Syrian resettlement in a post-accord context

\author{
Marion Schulz \\ Corresponding Author \\ Schulzmarion92@gmail.com
}

Laura K. Taylor, Ph.D.

Lecturer (Assistant Professor)

Centre for Identity and Intergroup Relations

School of Psychology

Queen's University, Belfast

Northern Ireland, United Kingdom

L.Taylor@qub.ac.uk 
SYRIAN RESETTLEMENT IN NORTHERN IRELAND 2

\section{The processes underlying the quality contact with the primary out-group and in-group importance on support for the Syrian resettlement in a post-accord context}

The current socio-political climate of Northern Ireland (NI) presents an intriguing setting to examine how, following a 30-year period of sectarian violence, individuals in a society of protracted intergroup conflict respond to other victimized groups. Syrian refugees were identified as the novel out-group due to the 2,000 Syrians refugees to be resettled in NI through the Syrian Vulnerable Persons Relocation Scheme. This paper was interested in understanding if the perceptions one has about the primary out-group in NI, generalize to a novel out-group entering the setting. It was hypothesized that higher quality of contact with the primary out-group would be positively related to support for Syrian resettlement in NI, whereas high in-group importance would be negatively related to this outcome. Moreover, the authors wanted to identify potential mechanisms through which the predictor variables influenced support for the Syrian resettlement. Participants ( $=378, M=27.40, S D=11.31$ years; $70 \%$ female; $58 \%$ Catholic, $42 \%$ Protestant) were recruited from community groups, local businesses, and universities. The results of the chain mediation models indicated the quality of contact with the primary out-group and ingroup importance were related (positively and negatively, respectively) with support for the Syrian resettlement via perspective taking and intergroup attitudes. These findings highlight that interventions to improve intergroup attitudes may facilitate support prior to and during resettlement. Application and relevance to social policies related to refugee resettlement are discussed.

Keywords: Northern Ireland, Syrian refugees, perspective taking, intergroup attitudes 
SYRIAN RESETTLEMENT IN NORTHERN IRELAND 3

The processes underlying the quality contact with the primary out-group and in-group importance on support for the Syrian resettlement in a post-accord context

The onset of the Syrian civil war in March 2011 served as a primary catalyst behind the $500 \%$ increase in asylum applications in the European Union. Consequently, the United Nations Refugee Agency (2016) estimates that there are currently 4.8 million Syrian refugees and, in Europe alone, an additional million asylum seekers. In response to this crisis, the former Prime Minister of the United Kingdom, David Cameron, launched the Vulnerable Persons Resettlement Program that pledged to resettle 20,000 Syrian refugees in the UK by 2020 . Northern Ireland (NI) agreed to accept 2,000 displaced Syrians and as of April 2016, 108 Syrian nationals were resettled there (McNulty, 2016). The resettlement in NI presents an intriguing setting to investigate how a post-accord society that, in the past, has suffered from sectarian violence, respond to a novel out-group, from a war struck country, entering the region.

Secondly, Pettigrew (1997) proposes the "secondary transfer effect," which postulates that the positive effects of contact with the primary out-group can generalize to novel out-groups, uninvolved in the existing paradigm, such as the Syrian refugees being resettled in NI. In a setting of protracted conflict, social identity theory (SIT; Tajfel \& Turner, 1979) outlines how high in-group importance and positive intergroup attitudes may also play opposing roles in support for the new arrivals. Thus, this paper investigated the relation between the quality of contact with the primary out-group and in-group importance as factors underlying of support for the Syrian resettlement. Secondly, this paper investigated potential underlying processes of the predictor factors. Perspective taking was theorized as the first mediator in the chain mediation $\left(M_{1}\right)$ that impacted the second mediator, intergroup attitudes $\left(M_{2}\right)$. That is, can the ability to think about the intergroup context, from the perspective of the 'other side,' increase understanding and subsequently attitudes towards the out-group resulting in higher intergroup 


\section{SYRIAN RESETTLEMENT IN NORTHERN IRELAND 4}

attitudes? Additionally, can the chain mediation via perspective taking and intergroup attitudes help explain the link between primary out-group contact and high in-group importance on Syrian resettlement?

\section{Primary out-group Contact}

Pettigrew (1997) postulated that positive contact with one's primary out-group may extend to novel out-groups that were not involved in the original conflict setting. That is, positive intergroup attitudes, referring to the primary out-group, may extend to new groups, such as the Syrian refugees in NI, through the secondary transfer effect (STE; Pettigrew, 2009). For example, in Italy, student's attitudes towards immigrants were found to extend to novel outgroups, such as members of the disabled community (Vezzali \& Giovannini, 2012). Likewise, positive orientations toward illegal immigrants extended to similar groups (i.e., legal immigrants and political refugees), but not towards unrelated groups (i.e., people who text and drive, terrorists; Harwood, Paolini, Joyce, Rubin, \& Arroyo, 2011). Based on the similarity of experiences of civilians caught between state and rebel violence in the Syrian conflict, it was hypothesized that individuals who hold more positive intergroup attitudes toward the primary out-group in NI would be more likely to support the novel target out-group, Syrian refugees.

Contact with primary out-group may be related to intergroup attitudes, depending on the quality of such contact (Allport, 1953; Pettigrew, Troop, Wagner, \& Christ, 2011). That is, better quality of past contact can have a positive influence on the present attitudes towards the primary out-group (Paolini, Harwood, Rubin, Husnu, Joyce, \& Hewstone, 2014). Likewise, positive contact with the primary out-group has been shown to promote primary and novel out-group helping (Johnston \& Glasford, 2017).

\section{Social Identity Approach and Intergroup attitudes}




\section{SYRIAN RESETTLEMENT IN NORTHERN IRELAND 5}

In a setting of protracted conflict however, perspective taking and out-group helping may also be influenced by other intergroup factors, for example the group's social identities. Social identity theory (SIT) is identified by Tajfel and Turner (1979) as a "part of an individual's selfconcept which derives from his knowledge of his membership in a social group together with the value and emotional significance attached to that membership" (p. 63). SIT developed as a way to understand the socio-psychological underpinnings of group membership and its functions (i.e., conflict between groups, the permeability of leaving the group, social hierarchy; Sindic \& Condor, 2014). Within this framework, intergroup relations are composed of the in-group, a group with which one shares similar qualities, interests or political-social identities (i.e., Catholics or Protestants in NI) and with which one finds a meaningful connection with the group identity. The out-group, a group with which one does not identity, can be rival football teams, supporters of diverse opinions or those with a different religious or political-social identities, as is the case in NI. For the purposes of this paper, the primary out-group refers to the direct 'other' within the NI context (i.e., if in-group is referring to the Catholic community the primary outgroup is the Protestant community). Additionally, out-groups outside the context of NI are referred to as the 'novel out-group' (i.e., Syrian refugees in NI).

Moreover, in regions that have experienced sectarian conflict the primary out-group can be shaped through disadvantages in social or political landscapes, violence, or skewed resources (i.e., Protestants and Catholics in NI; Palestinians and Israelis). These disadvantages can manifest into intergroup tension that can turn violent, as is the case with NI, a region in which the history of disadvantages in political and economic sectors lead to periods of violence, most recently the Troubles. In regards to the intergroup relations perspective, especially in areas of sectarian conflict, it can be helpful to look at different mechanisms that influence intergroup 
SYRIAN RESETTLEMENT IN NORTHERN IRELAND 6

relations such as in-group importance, contact with the primary out-group and intergroup attitudes.

\section{In-group Importance}

In particular, SIT underlies attitudes relating to in-group importance, or the tendency to favor one's in-group over other groups (Crockett, Everett, \& Faber, 2015), which can lead to ethnocentric inclinations that favor one's in-group (Smith \& Henry, 1996). For example, the inclination to act more favorably towards one's in-group has been shown in post-conflict Bosnia (Whitt \& Wilson, 2007) and in numerous economic game studies (Fehr, Bernhard, \& Rochenbach, 2008; Crockett et al., 2015). Moreover, in-group importance may be strengthened under conditions of threat of perceived extinction (Wohl, Branscombe, \& Reysen, 2010). For example, in NI, impact of the recent period of intergroup conflict, or the Troubles, was a predictor of stronger in-group identity, particularly among Catholic mothers (Goeke-Morey, Cairns, Taylor, Merrilees, Shirlow, \& Cummings, 2015). These findings suggest that those with higher in-group importance, or stronger attachment to their own social group, may be less likely to help other groups in need.

SIT also shapes primary out-group attitudes, or the feelings and perspectives that a group member holds about the primary out-group (i.e., prejudice, stereotypes, feelings and behavior intentions; Sherif, 1988) within a context setting. That is in NI, for the Catholic community group, the Protestant community is the primary out-group and vice versa.

For example, stronger attachment to the in-group may lead to greater differentiation and thus lower attitudes toward out-group members (Ferguson, Muldoon, \& McKeown, 2014); that is, those with higher in-group importance should have more negative primary out-group attitudes. Likewise, high in-group importance may also relate to lower support of a novel out- 
group, even when the suffering is similar (i.e., Syrian refugees) due to a greater differentiation between groups.

Perspective taking, however, may counteract the negative role of in-group importance and past negative experiences with the primary out-group by promoting similarities between groups (Galinsky \& Moskowitz, 2000). That is, perspective taking can promote positive intergroup attitudes through positive evaluations of the out-group (Galinsky \& Moskowitz 2000). Evidence for this positive association between perspective taking and intergroup attitudes has been found in in post-conflict settings (Vescio, Sechrist, \& Paolucci, 2003; Ugarriza \& Nussio, 2016).

\section{Perspective taking}

Perspective taking can be defined as the ability to understand how a situation appears to another person and how that person is reacting cognitively and emotionally to the situation. In the face of adversity, a host of negative outcomes may develop within an individual such as antisocial behaviors or mental health concerns (i.e., violence or PTSD/depression; Gillman, 1996; Herman, 1992). Hardship, however, may also motivate individuals to take an alternative path of altruism and prosocial behaviors (i.e., Altruism born of suffering (ABS); Staub \& Vollhardt, 2008). Likewise, perspective taking may develop from previous negative life events, including intergroup conflict, such as The Troubles in NI (Staub, 2003).

Perspective taking allows for constructive bystanders, or those who take "positive actions on behalf of individuals or groups" to improve society (Staub, 2016, p. 13), to envision the harm inflicted on someone, regardless of proximity, and inspire them to want to improve the welfare of the sufferer (Staub, 2016). Bystander responses to support those in need can be either physically or passive via support (Staub, 2016); the latter is the focus of the current paper. That 


\section{SYRIAN RESETTLEMENT IN NORTHERN IRELAND 8}

is, when an individual is capable of taking the perspective of a victim, it can motivate the individual to help (Staub, 2016). This process also works at the group-level (Mallett, Huntsinger, Sinclair, \& Swim, 2008). For example, Vollhardt and Bilali (2015) found that acknowledging the suffering of another group requires perspective taking and empathy. Thus, in terms of support for the Syrian resettlement, it was predicted that higher perspective taking would predict more support for the Syrian resettlement.

Second, perspective taking may be related to an individual's past suffering. Experiences of hardship and trauma may bestow within individuals heightened cognition; through a shared experience of distress, these individuals may be better equipped to understand the present condition of other victims (Vollhardt, 2009; Strumer \& Snyder, 2010). Moreover, Hartman and Morse (2015) found that as a result of the violence in Ivorian refugee crisis in Liberia, individuals developed 'altruistic behaviors' that transcended in-group boundaries and were directed toward the out-group (p. 28). Thus, past trauma or experience with conflict-related violence may motivate individuals to act in a prosocial manner, even toward out-group members. Empirical evidence of this was found amongst survivors of a terrorist bus hijacking in Israel whom adopted prosocial and altruistic behaviors towards others who had suffered from a range of violence (i.e., children with birth defects, helping other victims gain compensation; Vollhardt, 2009).

\section{NI Context}

Traditionally, the dissension in NI is between Protestants, who want to remain a part of the United Kingdom, and Catholics, who desire of a unified Republic of Ireland. It is notable that this conflict is not one of religion, but rather 'Protestant' and 'Catholic' refer to political-ethnic identities (Bull, 2006) formed through other aspects of culture (Darby, 1997; Shirlow \& 


\section{SYRIAN RESETTLEMENT IN NORTHERN IRELAND 9}

Murtagh, 2006). The Troubles, the most recent escalation of tensions, erupted in the 1960's in the form of civil rights protests over the disadvantages faced by Catholics in employment, housing, education and political affairs (Ferguson et al., 2014; Hancock, 1998). The Troubles formally ended with the signing of the Good Friday Agreement in 1998 which established a power sharing executive that required cross-community support for major decisions (Darby, 2003; Sergie, 2014).

In the era following the peace accord, NI has been relatively calm; however, lingering tensions in politics, community relations, and education have the potential to undermine the peace process (Darby, 2003). Moreover, in NI today, the education and housing sectors are $90 \%$ segregated by community background (Catholic or Protestant; Torney, 2012). To the extent that these structural issues impede positive intergroup relations and subsequently reduce the quality of intergroup contact. Although, some elements of social segregation remain in NI, the quality of intergroup contact has been shown to increase out-group helping, in other cases (Johnston \& Glasford, 2017; Tausch, Hewstone, Kenworthy, Psaltis, Schmid, Popan, Cairns, \& Hughes, 2010; Kauff, Schmid, Lolliot, Al Ramiah, \& Hewtone, 2016). Therefore, these structural barriers may partially have implications for offering support to novel out-group members in NI, such as the Syrian refugees.

Recent empirical evidence suggests that the attitudes of the two groups towards newcomers to NI vary. Compared to Catholics, Protestants reported more prejudice towards migrant groups (McDermott, 2014). In addition, compared to $60 \%$ of Protestants, $76 \%$ of Catholics reported feeling very favorable/favorable towards ethnic groups (ARK, 2015). These findings suggest that Catholics may hold more favorable views of migrant/ethnic groups in NI in general. This study wants to add to the current research by assessing if elements of the intergroup 
SYRIAN RESETTLEMENT IN NORTHERN IRELAND 10

context, shaped through the history of sectarian violence in NI, may influence support for novel out-groups. That is, can current attitudes about migrant groups in NI be, in part, explained through intergroup relations? Moreover, the authors were interested in if the quality of contact with the primary out-group and in-group importance influence (positively and negatively, respectively) support for a novel out-group.

\section{Current Study}

The current study sought to understand how individuals in a society of protracted intergroup conflict respond to other victimized groups. It was hypothesized that higher quality of contact with the primary out-group would be positively related to support for Syrian resettlement in NI, whereas as high in-group importance would be negatively related to this outcome.

Moreover, the authors wanted to identify potential mechanisms through which the predictor variables influenced support for the Syrian resettlement.

\section{Method}

\section{Participants}

This paper was part of a larger study on perceptions on social and political issues in NI. Participants ( $N=378, M=27.40, S D=11.31$ years old; $70 \%$ female) over 18 years old were recruited from community groups, businesses, non-profits and universities ${ }^{1}$. The inclusion criteria specified that participants must be from one of the two primary community backgrounds $(\mathrm{n}=218,58 \%$, Catholic; $\mathrm{n}=160,42 \%$, Protestant $)$ in Northern Ireland. Thus, participants who identified as having mixed backgrounds were excluded from the study.

\footnotetext{
${ }^{1} 54 \%$ of participants were university students. Independent t-test were performed on all variables in the model. Results indicated that there were no significant differences in: in-group importance $(t(351)=.294, \mathrm{p}=.769)$; perspective taking $(t(345)=-1.399$, $\mathrm{p}=.163)$; intergroup attitudes $(t(291)=1.538 \mathrm{p}=.125)$; support for Syria $(t(347)=-.113, \mathrm{p}=.910)$. However, the independent $\mathrm{t}$-test was significantly different for the quality of contact variable amongst the student and community sample $(t(359)=-2.446, \mathrm{p}=.015$ (university sample $\mathrm{M}=5.72, \mathrm{SD}=1.31$; community sample $\mathrm{M}=6.04, \mathrm{~S}=1.16$ )).
} 
SYRIAN RESETTLEMENT IN NORTHERN IRELAND 11

\section{Procedure}

The study was conducted under the approval of the ethics committee at Anonymous University. Data was collected using Qualtrics, an online survey program, over the course of eight months (October 2015 through April 2016). Participants were asked to provide consent before beginning the survey. Next, participants were asked to specify their age, gender and community background (Catholic or Protestant). After completing the survey, participants had the opportunity to enter a lottery for a chance to win one of three $£ 30$ Amazon gift vouchers. Lastly, the number of scale items, scale scoring and Cronbach alphas are reported in Table 1.

\section{Measures}

Quality of contact with primary out-group. This question was adapted from Tam, Hewstone, Kenworth, \& Cairns, (2009). Tam et al., (2009) used this question was used to look at the ability for intergroup contact to built intergroup trust in NI. This was presented as a single item question, "In general, when you meet people from the Catholic/Protestant community, do you find the contact pleasant or unpleasant?" Higher scores on this question indicated that contact was more pleasant than lower scores.

In-group importance. This scale was modified from the Roccas, Yechiel and Liviatan's (2006) in-group importance and glorification scale. This scale has been applied to transgenerational and endurance of in-group suffering (Kahn, Klar, \& Roccas, 2016) and the relation between existential threat and intergroup conflict (Hirschberger, Ein-Dor, Leidner, \& Saguy, 2016). The in-group importance scale included items such as, being Catholic/Protestant "is an important part of my identity," "it is important to me to view myself/it is important that others see me as Catholic/Protestant," etc.; higher scores indicated higher in-group importance. 
Perspective taking. This construct was measured with a subscale of the Prosocial Personality Battery (PBS; Penner, Fritzsche, Craiger, \& Freifeld, 1995). The perspective taking subscale included items such as "I sometimes try to understand my friends better by imagining how things look from their perspective" and "I believe that there are two sides to every question and try to look at them both." On this scale, higher scores indicated higher perspective taking.

Intergroup attitudes. This scale was adapted from the social reconstruction and forgiveness scale (Ajdukovic \& Biruski, 2008) used to assess nationalism in Croatia and Serbia (Biruski \& Penic, 2014). The target of the questions was the primary out-group in Northern Ireland (i.e., Catholics or Protestants). The scale included statements such as "I do not trust people from the other group" (reverse coded) and "I think it is important for our children to cooperate." Higher scores on this scale indicated higher intergroup attitudes.

Support for Syrian refugee resettlement. Participants responded to a modified version of the Syrian social distance scale (Bogardus, 1933). Social distance has been applied to social decisions (Akerlof, 1997) and attitudes towards ethnic minorities (Dyer, Vedlitz, \& Worchel, 1989). In this study, the Syrian social distance scale assesses support for resettlement using three items: "I would support allowing more Syrian refugees into Northern Ireland/my city/my neighborhood and school district."

\section{Data Analysis Plan}

This authors hypothesized that the quality of contact with the primary out-group in NI $\left(X_{1}\right)$ would extend to a novel out-group, that had suffered in a similar way, entering the existing intergroup paradigm (Syrian refugees $(\mathrm{Y})$ ) through perspective taking $\left(M_{1}\right)$ and intergroup attitudes $\left(M_{2}\right)$. Secondly, it was hypothesized that high in-group importance $\left(X_{2}\right)$ would reduce support for novel out-groups, such as the Syrian refugees (Y), through reduced perspective 
SYRIAN RESETTLEMENT IN NORTHERN IRELAND 13

taking $\left(M_{1}\right)$ and intergroup attitudes $\left(M_{2}\right)$. The correlations of the proposed predictor variables, mediators and support for Syrians were conducted using Pearson's correlations. To assess the ability of perspective taking $\left(M_{1}\right)$ and intergroup attitudes $\left(M_{2}\right)$ to account for the variance within $X_{1}$ and $X_{2}$ in predicting support for the Syrian resettlement in NI, chain mediation was used. A chain mediation model allows for the testing of the effect of $M_{1}$ on $M_{2}$, the combined effect of $M_{1}$ and $M_{2}$ (i.e., the total indirect effect) and the effect of each individual mediator while controlling for the other mediator (VanderWeele \& Vansteelandt, 2015). The direct and indirect effects of multiple mediator models can be estimated using regression analysis (VanderWeele \& Vansteelandt, 2015; Kenny 2016). The direct effect ('c' path) refers to the effect the independent variable on the outcome variable that is not accounted for by the chain mediation (i.e., or indirect effect of $M_{1}$ and $M_{2}$; Kenny, 2016). The indirect effect is the product of the 'a' paths (the relation of the independent variable on $M_{1}\left(a_{1}\right)$ and $M_{2}\left(a_{2}\right)$ ) and the ' $\mathrm{b}$ ' paths (the relation of the mediators on dependent variable; VanderWeele \& Vansteelandt, 2015). Lastly the 'c' path controls mediators and represents the total effect of the independent variable on the outcome variable (Kenny, 2016).

VanderWeele and Vansteelandt (2015) suggest bootstrapping for calculating standard errors of indirect effects. Secondly, bootstrapping is preferred for smaller samples and is less vulnerable to type I errors. The data in the current sample was resampled 10,000 times per recommendation from Hayes (2013). Bootstrapping generates confidence intervals (CI), which provide a range of values and confidence level (usually 95\%), within which, the 'true value' of a parameter exists (Flechner \& Tseng, 2011). When the CI does not contain 0 , the result is considered significant (Lane, 2013). Lastly, demographic data such as age and gender and community group background were controlled for in the chain mediation model. 


\section{SYRIAN RESETTLEMENT IN NORTHERN IRELAND 14}

\section{Results}

All analyses were conducted using IBM SPSS 24 (IBM, 2013). Table 1 includes means and standard deviations and Table 2 contains the bivariate correlations for all variables. Separate chain mediation analyses were conducted for testing the mediation of quality of primary outgroup contact $\left(X_{1}\right)$ and in-group importance $\left(X_{2}\right)$ via perspective taking $\left(M_{1}\right)$ and intergroup attitudes $\left(M_{2}\right)$, using Model 6 in the SPSS macro PROCESS (Hayes, 2012). The path coefficients are reported as unstandardized regression coefficients.

Figure $1^{2}$ depicts the chain mediation model for quality of contact with primary out-group $\left(X_{1}\right)$. This model evaluated if the relation between the quality of contact with the primary outgroup on support for a novel out-group (Syrian refugees) was mediated by perspective taking and intergroup attitudes. First, the 'a' paths ( $a_{1}$ (to perspective taking): $t(340)=2.445 p=.015 ; a_{2}$ (to intergroup attitudes): $t(339)=6.150, p<.001)$ and the ' $\mathrm{b}$ ' paths $\left(b_{1}: \mathrm{t}(338)=2.702, p=.007 ; b_{2}\right.$ : $t(338)=3.655, p<.001)$ were significant. Secondly, the path from $M_{1}$ to $M_{2}$ was significant $(t(339)=5.098, p<.001)$. The direct effect ( $c^{\prime}$ path) was insignificant $(t(338)=.603, p=.547)$; however, the total effect (c path) was significant $(t(340)=2.890, p=.020)$. The total indirect effect of quality of primary out-group contact on support for the Syrian resettlement was also significant $(.3844, \mathrm{CI}=.1871, .6631)$. The total indirect effect was comprised of $M_{1}(.08$, $\mathrm{CI}=.0103, .2304), M_{2}(.27, \mathrm{CI}=.1019, .5180)$ and the chain mediation of $M_{1}$ and $M_{2}(.03$, $\mathrm{CI}=.0059, .0816)$. Moreover, perspective taking and intergroup attitudes are both, independently and collectively, significant mediators of the relation between the quality of primary out-group contact and support for the Syrian resettlement.

\footnotetext{
${ }^{2}$ The mediational path from quality of contact through perspective taking and intergroup attitudes to support for the Syrian resettlement is not significant when quality of contact and perspective taking are reversed.
} 


\section{SYRIAN RESETTLEMENT IN NORTHERN IRELAND 15}

Figure 2 depicts the chain mediation model for in-group importance $\left(X_{2}\right)$ on support for the Syrian resettlement. This model assessed if the relation between high in-group importance on reduced support for a novel out-group (Syrian refugees) was mediated by perspective taking and intergroup attitudes. First, the ' $a$ ' paths ( $a_{1}$ (to perspective taking): $t(341)=-4.208, p<.001 ; a_{2}$ (to intergroup attitudes): $t(340)=-7.950, p<.001)$ and the ' $\mathrm{b}$ ' paths $\left(b_{1}: \mathrm{t}(339)=2.398, p=.01 ; b_{2}\right.$ : $t(338)=2.374, p=.01)$ were significant. Secondly, the path from $M_{1}$ to $M_{2}$ was significant $(t(340)=4.228, p<.001)$. The direct effect $\left(c^{\prime}\right.$ path; $\left.t(339)=-3.449, p=.01\right)$ and the total effect $(\mathrm{c}$ path; $t(339)=-6.479, p<.001)$ were significant, suggesting partial mediation. The total indirect effect of in-group importance on support for the Syrian resettlement was significant (-.0860, $\mathrm{CI}=-.1466,-.0297)$. The total indirect effect was comprised of $M_{1}(-.03, \mathrm{CI}=.-.0631,-.0043), M_{2}$ $(-.05, \mathrm{CI}=-.1075,-.0047)$ and the chain mediation of $M_{1}$ and $M_{2}(-.006, \mathrm{CI}=-.0167,-.0007)$. That is in-group importance reduces support for the Syrian resettlement via perspective taking and intergroup attitudes. As with primary out-group contact, perspective taking and intergroup attitudes are independently and collectively mediators of the relation between in-group importance on support for the Syrian resettlement.

\section{Discussion}

The primary aim of this research was to identify and understand which factors may promote or reduce support for Syrian refugee resettlement in a post-accord setting. The current study found significant chain mediation through perspective taking and intergroup attitudes to mediate the relation of the quality of primary out-group contact on support for a novel out-group. Greater perspective taking and positive intergroup attitudes may motivate individuals to have greater support for wider victim groups. There may be a shared experience of suffering with the Syrian refugees that facilitates stronger relations, particularly with regards to perspective taking. 
SYRIAN RESETTLEMENT IN NORTHERN IRELAND 16

That is, state oppression can be seen as a common link between the historic context of NI and displaced Syrians from the al-Assad regime. This shared identity of being victims of state oppression may underlie a motivation to support the resettlement. Likewise, the positive link between intergroup attitudes and support for resettlement, suggests that the way one perceives their intergroup context can extend to a novel out-group. Secondly, the similarity of past suffering may enhance this link. Future research, could look at victimized groups whom had suffered in dissimilar ways to assess if support generalized to disparate suffering.

Strong in-group importance, however, was linked with lower perspective taking and subsequently intergroup attitudes, resulting in reduced support for the resettlement. Weisel and Böhm (2015) found that help-avoidance towards the out-group was seldom used when the intergroup dynamic was between natural groups (i.e., football team supporters; Weisel \& Böhm, 2015). However, in a setting of protracted intergroup conflict, higher levels of in-group importance may exacerbate "social construction of difference" (Ferguson et al., 2014), or greater distinctions between "us" and "them," leading to in-group favoritism; such in-group preference which may underpin the lower support for the Syrian resettlement. Likewise, Weisel and Böhm (2015) found that when there was enmity between the in-group and the primary out-group helpavoidance was employed.

Secondly, the negative relation of higher in-group importance to support for the resettlement may suggest that individuals who prioritized the in-group, in turn, had lower perspective taking and lower intergroup attitudes, which were related to weaker support for helping Syrian refugees coming to NI. Likewise, Pettigrew $(1997,1998)$ suggested that primary out-group contact can lead to positive out-group attitudes via reappraisal of the in-group, which can create distance from the in-group, through gaining knowledge about diverse cultures via out- 
SYRIAN RESETTLEMENT IN NORTHERN IRELAND 17

group contact (Tausch et al., 2010). This in turn can result in less provincial perspectives towards out-groups in general (Pettigrew, 1997). However, the current study was interested in the role of high in-group importance and it could be the case that high in-group importance inhibits introspection of the in-group, which when paired with reduced primary out-group contact may restrict primary out-group attitudes and perspective taking which may subsequently extend to novel out-groups, via the secondary transfer effect.

Evidence of the secondary transfer effect was supported, suggesting that the quality of contact with the primary out-group may extend to novel out-groups entering the existing intergroup context. However, strong in-group importance may reduce support for novel outgroups, potentially through greater differentiation between the in-group and primary out-group (Ferguson, Muldoon, \& McKeown, 2014). Furthermore, building on the body of empirical work, these findings suggest that even individuals in a setting of protracted intergroup conflict may respond constructively and altruistically to help others in need (Staub, 2016).

\section{Limitations}

These findings should be interpreted in light of the study's limitations. First, there was a significant difference in the quality of contact with the primary out-group between the university student sample and community sample. That is, university students reported slightly lower quality contact with the primary out-group, compared to the community sample. To have a fuller understanding of this difference, future research could include primary out-group friendships as a predictor variable in the mediation model. These friendships have been shown to reduce primary out-group prejudice, as a predictor of out-group attitudes (Pettigrew, 1997). More specifically, Cairns, Gallagher, and Dunn (1993) found attending university to be an opportunity for intergroup contact; however, the contact reported was more casual than intimate (Hewstone, 


\section{SYRIAN RESETTLEMENT IN NORTHERN IRELAND 18}

Cairns, Voci, Paolini, McLernon, Crisp, \& Craig, (2005). Moreover, intergroup contact in secondary schools was associated with contact at the next education level in NI (Hewstone, et al., 2005). Therefore, future research could ask participants if they attended integrated schools and assess the relation of this experience with attitudes towards the primary out-group and assess if these attitudes generalize to support for novel out-groups.

Second, response scales used on the questionnaire offered five to seven potential responses, which might not have fully reflected the participant's opinion. To attempt to alleviate this concern, open-ended text boxes were provided, following each scale, although they were seldom used. Although the current study found that the relation of quality primary out-group contact and in-group importance on support for the resettlement were mediated through perspective taking and intergroup attitudes, future research should consider additional factors that facilitate support for victimized groups such as intergroup trust (Tam et al., 2009).

\section{Conclusion}

The results from this study could be used by those responsible for resettlement in NI; designing programs that help neighborhoods to support the resettlement is paramount to ease the stress of the transition for a refugee in a new country. For example, the findings highlight the importance of intergroup attitudes, suggesting that interventions to improve intergroup attitudes may have a secondary transfer effect that can facilitate support prior to and during resettlement. Past research has found, for example, that various types of contact may increase perspective taking (Wang, Kenneth, Ku \& Galinsky, 2014) and prosocial attitudes towards the primary outgroup members (Meleady \& Seger, 2016). Thus, working with host communities, via improved intergroup attitudes, prior to integration may increase acceptance and capacity to welcome Syrian nationals into these neighborhoods. Over the next five years, 2,000 Syrian refugees will 
make their way to NI. Studying public perceptions of the resettlement may provide insight for policy and law enforcement. These findings may have implications for how other societies with a history of intergroup violence may respond to the needs of a currently victimized group. 


\section{SYRIAN RESETTLEMENT IN NORTHERN IRELAND 20}

\section{References}

Ajdukovic, D., \& Biruski, D.C. (2008). Caught between the ethnic sides: children growing up in a divided post-war community. International Journal of Behavioral Development, 32, 337-347. doi:10.1177/0165025408090975

Akerlof, G. A. (1997). Social distance and social decisions. Econometrica, 65(5), 1005-1027. Retrieved from http://www.jstor.org/stable/2171877

Allport, G.W. (1953). The trend in motivational theory. American Journal of Orthopsychiatry, 23(1), 107-119. doi 0.1111/j.1939-0025.1953.tb00041.x

ARK. Northern Ireland Life and Times Survey. (2015). Retrieved from www.ark.ac.uk/nilt/ 2015/minority_ethnic_people/

Bogardus, E. S. (1933). A social distance scale. Sociology and Social Research, 17, 265-271.

Biruski, D.C. \& Penic, S. (2014). Traumatized selves: Does war trauma facilitate in-group bonding and out-group distancing? In Spini, D., Elcheroth, G., Biruski, D.C. (Eds.), War, community and social change: collective experiences in the former Yugoslavia, 137-154. Berlin \& New York: Springer

Bull, P. (2006). Shifting patterns of social identity in NI. The Psychologist. Retrieved from https://thepsychologist.bps.org.uk/volume-19/edition-1/shifting-patterns-social-identity-northernireland

Cairns, E., Gallagher, A.M. \& Dunn, S. (1993). Intergroup contact in a Northern Irish university setting: A report to the Central Community Relations Unit. Coleraine: Centre for the Study of Conflict, University of Ulster.

Darby, J. (2003). Northern Ireland: The background to the peace process. CAIN.

Darby, J. (1997). Scorpions in a bottle: Conflicting cultures in Northern Ireland. London: Minority Rights Publications

Dyer, J., Vedlitz, A., \& Worchel, S. (1989). Social distance among racial and ethnic groups in Texas: Some demographic correlates. Social Science Quarterly, 70(3), 607-616.

Crockett, M., Everett, J.A.C., \& Faber, N.S. (2015). Preferences and beliefs in in-group favoritism. Frontiers in Behavioral Neuroscience, 9-15. doi: 10.3389/fnbeh.2015.00015

Fehr E., Bernhard, H., \& Rockenbach, B. (2008). Egalitarianism in young children. Nature, 454, 1079-1083. doi:10.1038/nature07155 
Ferguson, N., Muldoon, O., \& McKeown, S. (2014). A political psychology of conflict: the case of Northern Ireland. In Nesbitt-Larking, P. (Eds.), Kinnvall, C. (Eds.), Capelos, T. (Eds.), The Palgrave handbook of global political psychology, 336-353. Palgrave. New York: New York.

Flechner, L. \& Tseng, T.Y. (2011). Understanding results: P-values, confidence intervals, and number need to treat. Indian Journal of Urology, 27(4), 532-535. doi: 10.4103/0970-1591.91447.

Galinsky, A.D., \& Moskowitz, G.B. (2000). Perspective-taking: Decreasing stereotype expression, stereotype accessibility, and in-group favoritism. Journal of Personality and Social Psychology, 78, 708-724.

Gillman, J. (1996). Violence: Our Deadly Epidemic and Its Causes. New York: Putnam.

Goeke-Morey, M.C., Cairns, E., Taylor, L.K., Merrilees, C.E., Shirlow, P., \& Cummings, E M. (2015). Predictors of strength of in-group identity in Northern Ireland: Impact of past sectarian conflict, relative deprivation, and church attendance. Journal of Community \& Applied Social Psychology, 25(4), 283-295.

Hancock, L. (1998). NI: Troubles brewing. NI Conflict Archive. Retrieved from http://cain.ulst.ac.uk/othelem/landon.htm

Harwood, J., Paolini, S., Joyce, N., Rubin, M. \& Arroyo, A. (2011). Secondary transfer effects from imagined contact: group similarity affects the generalization gradient. Behavioral Journal of Social Psychology, 50(1), 180-190. doi: 10.1348/014466610X524263.

Hartman, A.C., \& Morse, B.S. (2016). Wartime violence, empathy, and intergroup altruism: evidence from the Ivorian refugee crisis in Liberia. Retrieved from https://ssrn.com/ abstract= 2769889

Hayes A.F. (2013). Introduction to Mediation, Moderation, and Conditional Process Analysis: A Regression-Based Approach. New York, NY: Guilford Press.

Hayes, A. F. (2012). PROCESS: A versatile computational tool for observed variable mediation, moderation, and conditional process modeling [White paper]. Retrieved from http://www.afhayes.com/ public/process2012.pdf

Herman, J. (1992). Trauma and Recovery. New York: Basic.

Hewstone, M., Cairns, E., Voci, A., Paolini, S., McLernon, F., Crisp, R.J., Niens, U., \& Craig, J. (2005). Intergroup contact in a divided society: Challenging segregation in Northern Ireland. In D. Abrams, M. A. Hogg, \& J. M. Marques (Eds.), The social psychology of inclusion and exclusion (pp. 265-293). New York, NY: Psychology Press. 
Hirschberger, G., Ein-Dor, T., Leidner, B. \& Saguy, T. (2016). How Is Existential Threat Related to Intergroup Conflict? Introducing the Multidimensional Existential Threat (MET) Model. Personality and Social Psychology. doi10.3389/fpsyg.2016.01877

IBM Corp. (2013). IBM SPSS Statistics for Windows, Version 22.0. Armonk, NY: IBM Corp.

Johnston, B.M., \& Glasford, D. E. (2017). Intergroup contact and helping: How quality contact and empathy shape outgroup helping. Group Processes \& Intergroup Relations. doi $10.1177 / 1368430217711770$

Kahn, D., Klar, Y., \& Roccas, S. (2006). Fore the sake of the eternal group: Perceiving the group as trans-generational and endurance of in-group suffering. Personality and Social Psychology bulletin.

Kauff, M., Schmid, K., Lolliot, S., Al Ramiah, A., \& Hewtone, M. (2016). Intergroup Contact Effects via In-group Distancing among Majority and Minority Groups: Moderation by Social Dominance Orientation. PLOS. Retrieved from https://doi.org/10.1371/journal.pone.0146895

Kenny, D. A. (2016). Mediation. Retrieved from http://davidakenny.net/cm/mediate.htm

Lane, D. M. (2013). Introduction to Statistics: An Interactive eBook.

Mallett, R., Huntsinger, J.R., Sinclair, S., \& Swim, J.K. (2008). Seeing through their eyes: When majority group members take collective action on behalf of an out-group. Group Processes and Intergroup Relations, 11(4), 451-470. doi: 10.1177/1368430208095400

McDermott, P. (2014). Attitudes towards minority ethnic people and migrant workers 2014: Research update. Access Research Knowledge. Retrieved from http://www.ark.ac.uk/ publications/updates/update103.pdf

McNulty, M. (2016). Refugees in NI 2016. Embrace NI. Retrieved from https://www. embraceni.org/wp-content/uploads/2012/09/Refugee-booklet-10.3.pdf

Meleady, R., \& Seger, C.R. (2016). Imagined contact encourages prosocial behavior towards out-group members. Sage Journals. doi. 10.1177/1368430215612225

Paolini, S., Harwood, J., Rubin, M., Husnu, S., Joyce, N., \& Hewstone, M. (2014). Positive and extensive intergroup contact in the past buffers against the disproportionate impact of negative contact in the present. European Journal of Social Psychology. doi 10.1002/ejsp.2029

Penner, L.A., Fritzsche, B.A., Craiger, J.P., \& Freifeld, T.R. (1995). Measuring the prosocial personality. In J. Butcher \& C. D. Spielberger (Eds.) Advances in Personality Assessment, 10. Hillsdale, NJ: LEA.

Pettigrew, T.F. (1997). Generalized intergroup contact effects on prejudice. Personality Social Psychology Bulletin, 23, 173-185. 
Pettigrew, T. F. (1998). Intergroup contact theory. Annual Review of Psychology, 49, 65-85.

Pettigrew, T.H. (2009). Secondary transfer effect of contact. Social Psychology, 40, 55-65. doi: $10.1027 / 1864-9335.40 .2 .55$

Pettigrew, T. F., Troop, L.R., Wagner, U., \& Christ, O. (2011). Recent advances in intergroup contact theory. International Journal of Intercultural Relations, 35(3), 271-280.

Roccas, S., Yechiel, K. \& Liviatan, I. (2006). The paradox of group-based guilt: Modes of national identification, conflict vehemence and reactions to in-group's moral violations. Journal of personality and social psychology, 91(4), 698-711.

Sergie, M.A. (2014). The Northern Ireland Peace Process. Council on Foreign Relations. Retrieved from https://www.cfr.org/backgrounder/northern-ireland-peace-process

Sherif, M. (1988). Intergroup Conflict and Cooperation: The Robbers Cave Experiment. Institute on Group relations. University of Oklahoma.

Shirlow, P., \& Murtagh, B. (2006). Belfast: Segregation, Violence and the City. Dublin: Pluto Press

Sindic, D., \& Condor, S. (2014). Social identity theory and self categorization theory. In NesbittLarking, P. (Eds.), Kinnvall, C. (Eds.), Capelos, T. (Eds.), The Palgrave handbook of global political psychology, 336-353. Palgrave. New York: New York.

Smith, E. R., \& Henry, S. (1996). An in-group becomes part of the self: Response time evidence. Personality \& Social Psychology Bulletin, 22, 635-642.

Staub, E. (2003). The Psychology of Good and Evil: Why Children, Adults and Groups Help and Harm Others. New York: Cambridge University Press.

Staub, E., \& Vollhardt, J.R. (2008). Altruism born of suffering: The roots of caring and helping after victimization and other trauma. American Journal of Orthopsychiatry, 78, 267-280. doi: $10.1037 / \mathrm{a} 0014223$

Staub, E. (2016). The Roots of Goodness and Resistance to Evil. Oxford: Oxford University Press.

Strumer, S. \& Snyder, M. (2010). Psychology of Prosocial Behaviors: The Group Processes, Intergroup Relations and Helping. United Kingdom: Wiley-Blackwell

Tajfel, H. (Ed.) (1978). Differentiation between social groups. European Monographs in Social Psychology, 14. London: Academic Press 
Tajfel, H., \& Turner, J.C. (1979). An Integrative Theory of Intergroup Conflict. In W.G. Austin $\&$ S. Worchel (Eds.), The Social Psychology of Intergroup Relations. Monterey, CA: BrooksCole

Tam, T., Hewstone, M., Kenworth, J., \& Cairns, E. (2009). Intergroup trust in Northern Ireland. Personality and Social Psychology Bulletin, 35, 45-49.

Tausch, N., Hewstone, M., Kenworthy, J.B., Psaltis, C., Schmid, K., Popan, J., Cairns, E., \& Hughes, J. (2010). Secondary transfer effects of intergroup contact: Alternative accounts and underlying processes. Journal of Personality and Social Psychology, 99, 282-302.

Torney, K. (2012). How Integrated are schools where you live? Retrieved from https://www.thedetail.tv/articles/how-integrated-are-schools-where-you-live

Turner, J.C. (1985). Social Categorization and the Self-Concept: A Social Cognitive Theory of Group Behaviour. Advances in Group Processes, 77-121. Edited by Edward J. Lawler. Greenwich, CT: JAI

Ugarriza, J.E., \& Nussio, E. (2016). The effect of perspective taking on post-conflict reconciliation. An experimental approach. Political Psychology, 38-1, 3-19. doi:

10.1111/pops. 12324

VanderWeele., T.J., \& Vansteelandt, S. (2014). Mediation Analysis with Multiple Mediators. Epidemiologic Methods, 2(1), 95-115. http://doi.org/10.1515/em-2012-0010

Vescio, T.K., Sechrist, G.B. and Paolucci, M.P. (2003). Perspective taking and prejudice reduction: the mediational role of empathy arousal and situational attributions. European Journal of Social Psychology, 33, 455-472. doi:10.1002/ejsp.163

Vezzali, L. \& Giovannini, D. (2012). Secondary Transfer Effect of Intergroup Contact: The Role of Intergroup Attitudes, Intergroup Anxiety and Perspective Taking. Journal of Community applied social psychology, 22, 125-144. doi:10.1002/casp.1103

Vollhardt, J.R. (2009). Altruism born of suffering and prosocial behaviors following adverse life events: A review and conceptualization. Social Justice Research, 22, 53-97. doi:

10.10007/s11211-009-0088-1

Vollhardt, J.R., \& Bilali, R. (2015). The role of inclusive and exclusive victim consciousness in predicting intergroup attitudes: Findings from Rwanda, Burundi, and DRC. Political Psychology, 36, 489-506. doi:10.1111/pops. 12174

Wang, C.S., Kenneth, T., Ku, G., \& Galinsky, A.D. (2014). Perspective-taking increases willingness to engage in intergroup contact. PLOS ONE, 9(1), e85681. doi.

10.1371/journal.pone.0085681 
Whitt, S., \& Wilson R.K. (2007). The dictator game, fairness and ethnicity in postwar Bosnia. Journal of Political Science, 51, 655-668. doi 10.1111/j.1540-5907.2007.00273

Weisel, O., \& Böhm, R. (2015). "In-group love" and "out-group hate" in intergroup conflict between natural groups. Journal of Experimental Social Psychology, 60, 110-120, retrieved from https://doi.org/10.1016/j.jesp.2015.04.008

Wohl, M.J.A., Branscombe, N.R., \& Reysen, S. (2010). Perceiving your group's future to be in jeopardy: Extinction threat induces collective angst and the desire to strengthen the ingroup. Personality and Social Psychology Bulletin ,36, 898-910. doi:

$10.1177 / 0146167210372505$

United Nations Refugee Agency. (2016). Facts and figures. Received from http://www.unhcr.org/uk/ 
SYRIAN RESETTLEMENT IN NORTHERN IRELAND 26

Table 1. Means and standard deviations

\begin{tabular}{lcc}
\hline Measure & M & SD \\
\hline \hline Age & 27.47 & 11.36 \\
$\begin{array}{l}\text { Gender } \\
\text { Perspective taking } \\
(4,1-7, .71)\end{array}$ & - & - \\
$\begin{array}{l}\text { Quality of contact with } \\
\text { primary out-group (1, 1-7) }\end{array}$ & 27.32 & 4.49 \\
$\begin{array}{l}\text { In-group Importance } \\
(3,1-7, .92)\end{array}$ & 10.82 & 1.25 \\
$\begin{array}{l}\text { Intergroup attitudes } \\
(7,1-7, .83)\end{array}$ & 51.03 & 5.75 \\
$\begin{array}{l}\text { Support for Syrians } \\
(3,1-7, .99)\end{array}$ & 15.58 \\
$\begin{array}{l}\text { Beneath the construct, in parenthesis, are the number of } \\
\text { scale items, scoring of the scale and Cronbach's alpha }\end{array}$
\end{tabular}


SYRIAN RESETTLEMENT IN NORTHERN IRELAND 27

Table 2. Bivariate correlations

\begin{tabular}{lcccccccc}
\hline & 1 & 2 & 3 & 4 & 5 & 6 & 7 & 8 \\
\hline \hline 1. Age & - & & & & & & & \\
2. Gender & -.09 & - & & & & & & \\
3. Community group membership & -.04 & -.01 & - & & & & & \\
4. Perspective taking & .09 & .04 & .02 & - & & & \\
5. Quality of out-group contact & .08 & .03 & .02 & $.15^{* * *}$ & - & & \\
6. In-group Importance & .06 & .06 & -.10 & $-.22^{* * *}$ & $-.21^{* *}$ & - & & \\
7. Intergroup attitudes & $-.14^{* *}$ & .09 & -.09 & $.28^{* * *}$ & $.31^{* *}$ & $-.42^{* *}$ & - & \\
8. Support for Syrians & .02 & -.05 & $-.29^{* *}$ & $.20^{* *}$ & $.12^{*}$ & $-.25^{* *}$ & $0.27^{* *}$ & - \\
& $* \mathrm{p}<.05 ; * * \mathrm{p}<.01 ; * * \mathrm{p}<.001$ & & & &
\end{tabular}


Figure 1. Unstandardized regression coefficients for the chain mediation model via perspective taking and intergroup attitudes for the effect of quality of contact with primary out-group on support for Syrian refugee resettlement. ${ }^{*} p<.05 ; * * p<.01 ; * * * p<.001$

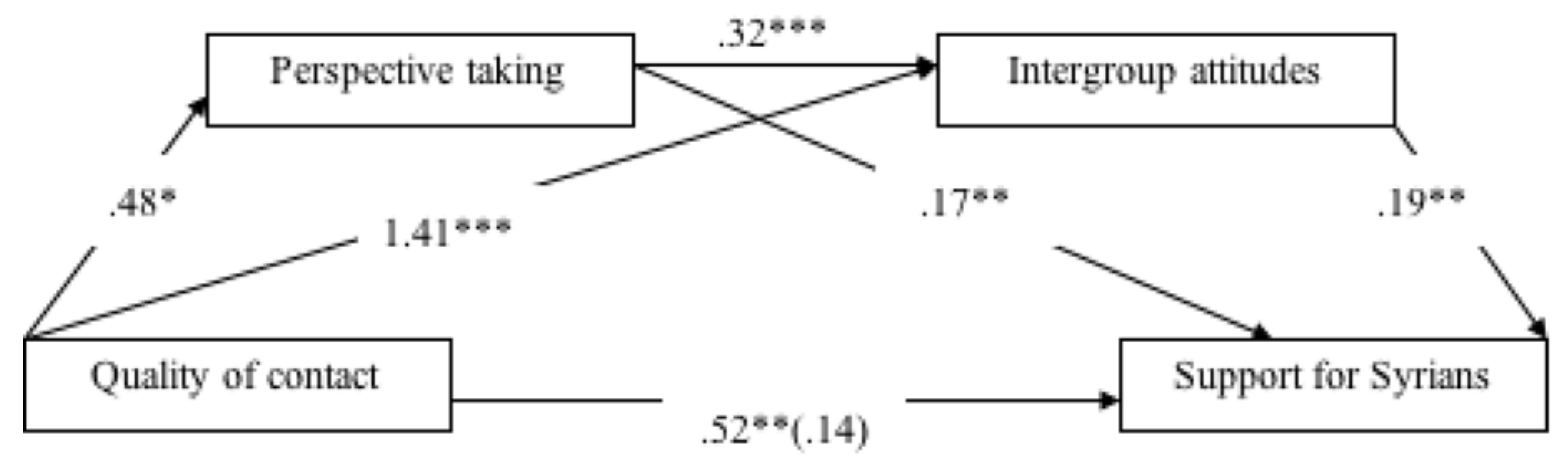


Figure 2. Unstandardized regression coefficients for the chain mediation model via perspective taking and intergroup attitudes for the effect of in-group importance on support for Syrian refugee resettlement. ${ }^{*} p<.05 ; * * p<.01 ; * * * p<.001$

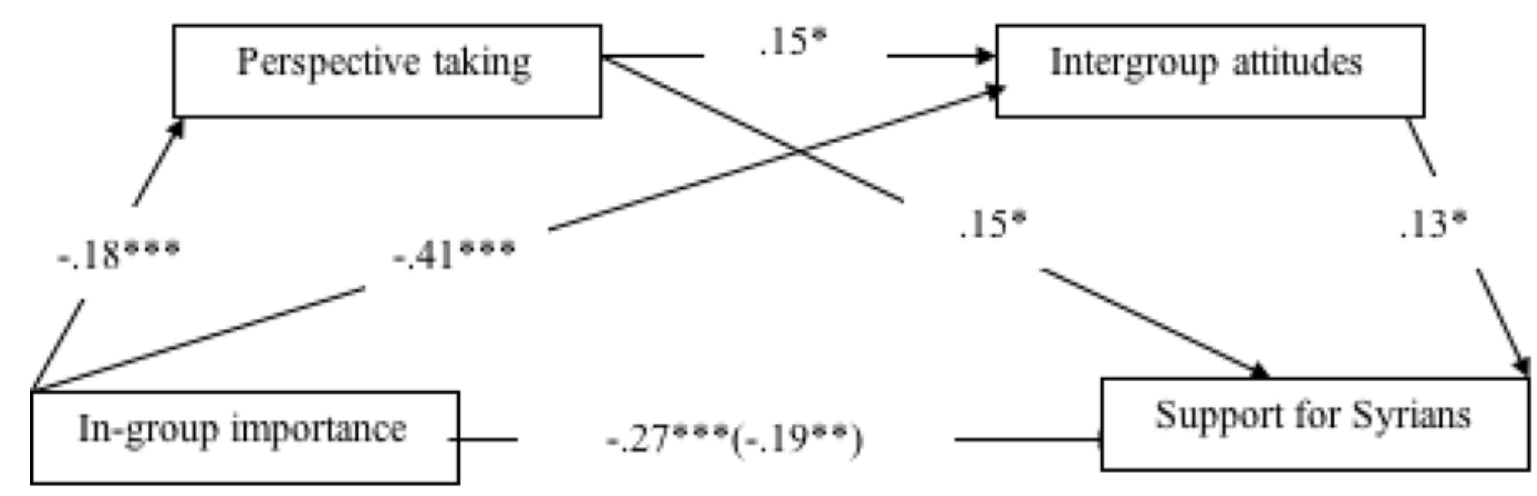

